J. Clin. Chem. Clin. Biochem.

Vol. 22, 1984, pp. 473-478

\title{
Effect of Magnesium Injection on Foetal Development
}

\author{
By T. Günther, J. Vormann \\ Institut für Molekularbiologie und Biochemie, Freie Universität Berlin and
}

\section{H. J. Merker}

Institut für Embryonalpharmakologie, Freie Universität Berlin

(Received November 25, 1983/March 27, 1984)

Summary: Pregnant rats were subcutaneously injected twice daily with $1.5 \mathrm{ml} 150 \mathrm{mmol} / \mathrm{l} \mathrm{MgCl} 2$ beginning at day 5 of gestation. By this treatment development of foetal liver and pancreas was enhanced. In the foetal liver, there was a precocious glycogenolysis combined with a precocious development of the smooth endoplasmic reticulum (ER) and an irregular arrangement of the rough ER. In the pancreas, the development of secretory granules was enhanced.

In alizarin red-stained and cleared specimens, the foetal skeleton was less calcified. The injected $\mathrm{Mg}^{2+}$ remained extracellular. Altered hormonal secretion and/or an altered activity of the regulatory enzymes of glycogen metabolism induced by the increased extracellular $\mathrm{Mg}^{2+}$ concentration are discussed as possible mechanisms for enhanced foețal liver development.

\section{Wirkung von Magnesium-Injektionen auf die Foetalentwicklung}

Zusammenfassung: Schwangeren Ratten wurde zweimal täglich $1,5 \mathrm{ml} 150 \mathrm{mmol} / \mathrm{l} \mathrm{MgCl}_{2}$-Lösung, beginnend vom Tag 5 der Gravidität, subcutan injiziert. Durch diese Behandlung erfolgte in der foetalen Leber eine vorzeitige Glykogenolyse, verbunden mit einer vorzeitigen Entwicklung des glatten endoplasmatischen Retikulums (ER) und einer unregelmäßigen Anordnung des rauhen ER.

Im Pankreas war die Entwicklung von exkretorischen Vesikeln beschleunigt.

Das foetale Skelett war in geringerem Maße calcifiziert.

Das injizierte $\mathrm{Mg}^{2+}$ verblieb im Extrazellulärraum.

Als Mechanismus für die beschleunigte foetale Leber-Entwicklung wurden eine geänderte Hormonsekretion und/oder veränderte Aktivitäten der regulatorischen Enzyme des Glykogenstoffwechsels, ausgelöst durch die erhöhte extrazelluläre $\mathrm{Mg}^{2+}$-Konżentration, angenommen.

\section{Introduction}

In tocolytic therapy with $\beta$-agonists $20.5 \%$ of the newborns exhibit hypotrophy according to the chosen score. When, during tocolysis, patients were supplemented with $\mathrm{Mg}^{2+}(15-20 \mathrm{mmol} /$ day $)$, only $8.8 \%$ of the newborns were hypotrophic, i.e. the same frequency of occurence as in normal pregnancy $(8-11 \%)(1)$.
When pregnant rats were injected daily with $\mathrm{MgSO}_{4}$ ( $150 \mathrm{mg} / \mathrm{kg}$ body weight) from day 5 of pregnancy, the foetal livers at term were well developed with morphofunctional features closely resembling those of the adult organs (2).

From these observations, it seems that chronic $\mathrm{Mg}^{2+}$ supplementation during pregnancy may enhance 
foetal development. We therefore investigated foetal development, to find at which stage of pregnancy it is enhanced by $\mathrm{Mg}^{2+}$, which foetal organs are concerned, and the nature of the biochemical mechanism responsible for the effect.

\section{Materials and Methods}

Wistar rats weighing $200 \mathrm{~g}$ were used in the experiments. The rats were maintained under a 12-hour light-dark cycle and at a temperature of about $20^{\circ} \mathrm{C}$. Virgin females were mated from 8-10 a.m. and impregnated females were identified by the presence of copulatory plugs. This day was designated as day 0 of gestation. The animals were fed with Altromin (Altromin, Lage, FRG) $\left(\mathrm{Mg}^{2+}\right.$ content: $83 \mathrm{mmol} / \mathrm{kg}, \mathrm{Ca}^{2+}$ content: $\left.220 \mathrm{mmol} / \mathrm{kg}\right)$ and tap water $\left(\mathrm{Mg}^{2+}\right.$ content: $\left.0.5 \mathrm{mmol} / \mathrm{l}\right)$ ad libitum.

\section{Morphology}

Some of the pregnant rats were subcutaneously injected twice per day at 9 a.m. and 4 p. m. with $1.5 \mathrm{ml} 150 \mathrm{mmol} / \mathrm{l} \mathrm{MgCl}$. At day $10,11,12,13,15,17,19,20$ and 21 of pregnancy, two $\mathrm{Mg}^{2+}$-injected and one control rat were killed. Up to day 13 the number of somites was calculated. Foetuses from day 10 to 17 were fixed in toto in $30 \mathrm{~g} / \mathrm{l}$ paraformaldehyde and $30 \mathrm{~g} / \mathrm{l}$ glutaraldehyde in 0.2 $\mathrm{mol} / \mathrm{l}$ cacodylate buffer $\mathrm{pH} 7.2$ for electron microscopy and in $35 \mathrm{~g} / \mathrm{l}$ formaldehyde for light microscopy and alizarin red-staining. From day 19-21, separated tissues were fixed for electron microscopy and histology. For electron microscopy, postfixation

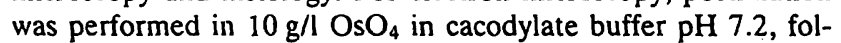
lowed by dehydration in ethanol, embedding in Mikropal, sectioning with Reichert and LKB microtomes, and contrasting in uranyl acetate/lead citrate. Electron microscopy was performed with Zeiss EM 10 and Siemens 101. For histology, slices were stained in haematoxilin-eosin (HE).

For detection of skeletal development, foetuses from day 19 to 21 were fixed in formalin, stained with alizarin red, cleared in $\mathrm{NaOH}$, and stored in glycerol.

\section{$\mathrm{Mg}^{2+}$ metabolism}

To determine whether $\mathrm{MgCl}_{2}$ injected into the mothers is taken up by foetal tissues, pregnant rats were injected 7 times every 4 hours with $1.5 \mathrm{ml} 150 \mathrm{mmol} / \mathrm{l} \mathrm{MgCl}$ beginning from day 18 at 9 a. $m$. At day 19 , the rats were killed at various times after the last injection.

Foetal blood, heart, liver and maternal blood were taken under pentobarbital (Nembutal ${ }^{\circledR}$ ) anesthesia $(50 \mathrm{mg} / \mathrm{kg}$ ). For experimental details see l.c. (3).

In a second experiment, after laparotomy in pentobarbital anesthesia, half of the foetuses in each pregnant rat were s.c. injected with $75 \mu \mathrm{l} 150 \mathrm{mmol} / \mathrm{l} \mathrm{MgCl}$. After two hours, foetal blood, heart, liver, and maternal blood were taken.

Foetal hearts and livers were freeze-dried. For determination of electrolyte content, the freeze-dried tissues were ashed overnight in a Low Temperature Asher (Tracerlab), dissolved in $0.1 \mathrm{~mol} / \mathrm{l}$ $\mathrm{HCl}$ containing $1 \mathrm{~g} / 1 \mathrm{La}^{3+}$. After dilution with $\mathrm{H}_{2} \mathrm{O}$, containing $1 \mathrm{~g} / \mathrm{L} \mathrm{La}^{3+}, \mathrm{Mg}^{2+}$ and $\mathrm{Ca}^{2+}$ were measured in an atomic absorption spectrophotometer (Perkin-Elmer, model 300). After dilution with $30 \mathrm{mmol} / \mathrm{l} \mathrm{LiCl}, \mathrm{Na}^{+}$and $\mathrm{K}^{+}$were measured in a flame photometer (Beckman). All solutions were made with Millipore water. For details see 1. c. (3).

\section{Results}

\section{Growth rate}

When pregnant rats, fed with the normal $\mathrm{Mg}^{2+}$ rich food, were injected with $\mathrm{MgCl}_{2}$ from day 5, the number of the somites in the foetuses at day 10,11 , 12 and 13 was unchanged (tab. 1). Also the weight of the foetuses at day 20 and 21 was unaltered (tab. 2). Therefore, growth rate was not affected under our conditions of $\mathrm{Mg}^{2+}$ supplementation.

Tab. 1. Number of somites of foetuses from $\mathrm{MgCl}_{2}$-injected and untreated pregnant rats. Mean $\pm S E M, n=$ number of foetuses.

\begin{tabular}{lrccc}
\hline Day & n & Control & $\mathrm{n}$ & $\mathrm{MgCl}_{2}$-injected \\
\hline 10 & 8 & $5-7$ & 16 & $5-7$ \\
11 & 25 & $25.4 \pm 0.4$ & 18 & $23.9 \pm 0.3$ \\
12 & 9 & $35.3 \pm 0.2$ & 17 & $35.3 \pm 0.1$ \\
13 & 5 & $44.6 \pm 0.4$ & 8 & $.42 .1 \pm 0.6$ \\
\hline
\end{tabular}

Tab. 2. Weight (g) of the foetuses from $\mathrm{MgCl}_{2}$-injected and untreated pregnant rats. Mean $\pm S E M$. $n=$ number of foetuses.

\begin{tabular}{rrrrr}
\hline Day & $\mathrm{n}$ & Control & $\mathrm{n}$ & $\mathrm{MgCl}_{2}$-injected \\
\hline 20 & 9 & $3.49 \pm 0.08$ & 18 & $3.40 \pm 0.05$ \\
21 & 12 & $4.60 \pm 0.11$ & 14 & $4.71 \pm 0.07$ \\
\hline
\end{tabular}

$\therefore=\cdots$

\section{Morphology}

\section{Liver}

The deposition of glycogen, usually beginning at day 17, was the same in both foetal groups. However, beginning at day 19 , the glycogen content was lower in the $\mathrm{Mg}^{2+}$-treated foetuses than in the controls. From day 20 to 21 , in the $\mathrm{Mg}^{2+}$-treated foetuses, the glycogen content decreased, whereas in the controls, glycogen increased further. From this result one can conclude that the lower glycogen content in the $\mathrm{Mg}^{2+}$-treated group is caused by glycogenolysis. $\mathrm{Pa}-$ rallel with the reduction of glycogen content, there was an increase in the amount of smooth endoplasmic reticulum (ER). The rough $E R$, normally ordered in parallel was in part irregularly arranged and in contact with mitochondria. Similar behaviour was seen when the biosynthesis of mitochondria was enhanced (4). Cell membranes, mitochondria and nucleus of the hepatocytes were not affected by $\mathrm{Mg}^{2+}$ treatment (figs. 1, 2): 


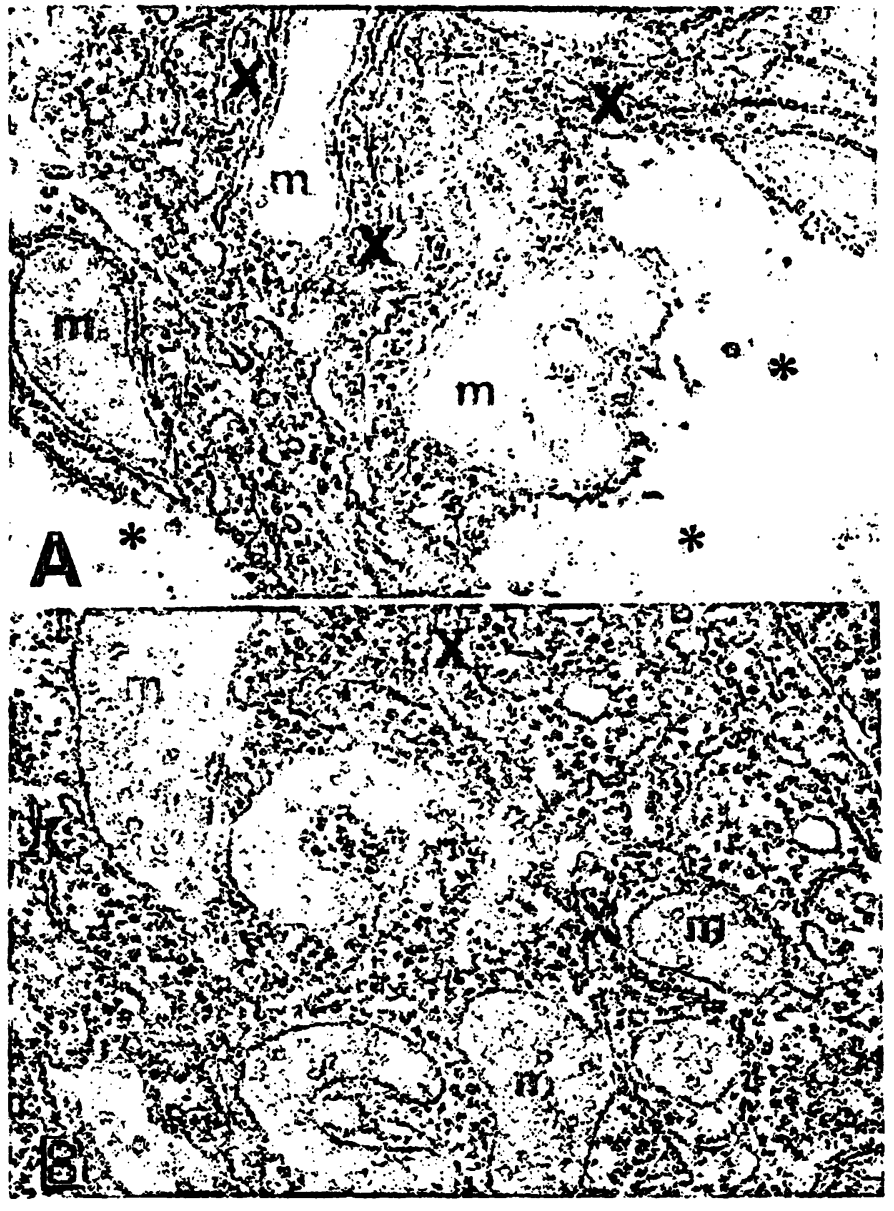

Fig. 1.

A Part of a liver cell from a control rat foetus day 19 with large glycogen-filled areas ( $\star)$, mitochondria $(m)$ and cavities of the rough endoplasmic reticulum, packed in a parallel manner $(x) . \times 25000$.

B Part of a liver cell from a $\mathrm{MgCl}_{2}$-treated rat foetus, day 19. No glycogen deposits and an irregular course of the cavities of the rough $E R(x) . m=$ mitochondria. $\times 25000$.

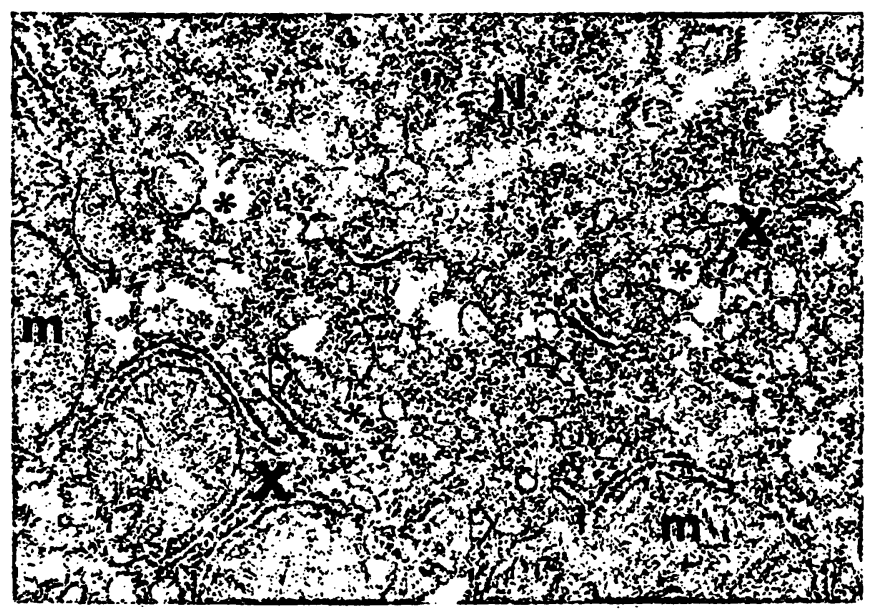

Fig. 2. Part of a rat liver cell from a day 20 foetus after treatment with $\mathrm{MgCl}_{2}$. Residues of glycogen ( $\star$ ). Increase of smooth endoplasmic reticulum ( $(\not) . m=$ mitochondria, $N=n u-$ cleus. Most of the cavities of the rough endoplasmic reticulum are isolated $(x) . \times 25000$.
Other cell types of the foetal liver were not significantly changed. The accelerated development by $\mathrm{Mg}^{2+}$-injection did not reach the adult state; adult liver still has less glycogen and more smooth ER than foetal liver after $\mathrm{Mg}^{2+}$-treatment.

\section{Adrenals}

As glucocorticoid hormones play a permissive role in glycogen synthesis in foetal liver (5), the development of the adrenals was electronmicroscopically investigated. However, there were no significant qualitative morphological differences in the development of foetal adrenals from untreated and $\mathrm{MgCl}_{2}$-treated pregnant rats.

\section{Pancreas}

As insulin and glucagon are involved in the regulation of glycogen metabolism and as the ratio insulin/ glucagon is perinatally changed (6), the behaviour of pancreatic islets was investigated. The foetal pancreatic islets from $\mathrm{MgCl}_{2}$-treated pregnant rats showed no changes in the normal pattern of development, and significant morphological differences between the control foetuses and those from $\mathrm{MgCl}_{2}-$ treated mothers were not observed.

However, the development of the excretory part of the pancreas was enhanced by $\mathrm{MgCl}_{2}$-treatment. Beginning from day 17 and more expressed at later stages, the excretory cells from $\mathrm{MgCl}_{2}$-treated foetuses contain more ER and excretory vesicles than those from untreated controls. Some material was already excreted into the ductus (fig. 3 ).

\section{Lung, kidney}

In the lungs and kidneys of foetuses from $\mathrm{MgCl}_{2}$-injected and non-injected pregnant rats, no significant morphological alterations could be seen by light and electron microscopy.

\section{Skeleton}

In the foetuses of $\mathrm{MgCl}_{2}$-injected mothers, the pattern of the skeleton was not altered but the mineralization of all bones was reduced in Alizarin redstained and cleared specimens. This could be seen best in the tail. As the bones of the tail are the last to be mineralized, the number of tail vertebrae was lower than in the controls (fig. 4). 




Fig. 3.

A Exocrine pancreas cell from a control rat foetus, day 19 , with numerous cavities of the rough ER $(x)$ and free ribosomes. Note the absence of secretory granules. $\mathrm{N}=$ nucleus. $\times 7500$.

B Exocrine pancreas cell from an $\mathrm{MgCl}_{2}$-treated rat foetus with numerous cavities of the rough $\mathrm{ER}(X)$ and secretory granules $(\boldsymbol{\theta})$. Nucleus $(\mathrm{N})$ with large nucleoli (*). $\times 7500$.

This result is in agreement with in-vitro mineralization experiments. ${ }^{45} \mathrm{Ca}^{2+}$ incorporation in bone was also reduced by competition with $\mathrm{Mg}^{2+}$, when the extracellular $\mathrm{Mg}^{2+}$ concentration was increased (7).

\section{$\mathrm{Mg}^{2+}$ metabolism}

In pregnant rats, subcutaneously injected every 4 hours with $1.5 \mathrm{ml} 150 \mathrm{mmol} / \mathrm{l} \mathrm{MgCl}$, the serum $\mathrm{Mg}^{2+}$ concentration 30 min p.i. was increased to 3.1 $\mathrm{mmol} / \mathrm{l}$ and dropped rapidly to $1.2 \mathrm{mmol} / \mathrm{l}$ within 4 hours after injection (fig. 5). This subsequent fall is due to excretion and to the adsorption of $\mathrm{Mg}^{2+}$ to bone.

Serum $\mathrm{Mg}^{2+}$ concentration in the corresponding foetal rats only changed between 2.1 and $1.7 \mathrm{mmol} / \mathrm{l}$. Foetal serum $\mathrm{Mg}^{2+}$ in this experiment was therefore permanently increased between $10 \%$ and $40 \%$ for

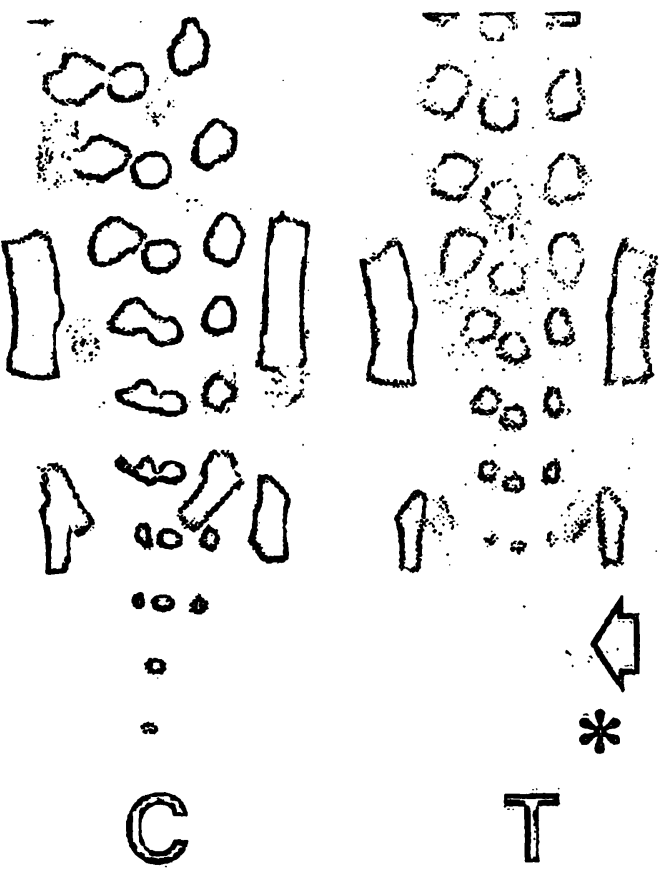

Fig. 4. The caudal portions of a control (C) and an $\mathrm{MgCl}_{2}$-treated (T) rat foetus, day 19 , alizarin red-staining and cleared. Note the lower alizarin red uptake $(\emptyset)$ or absence $(*)$ of the bone centres in the tail vertebrae.

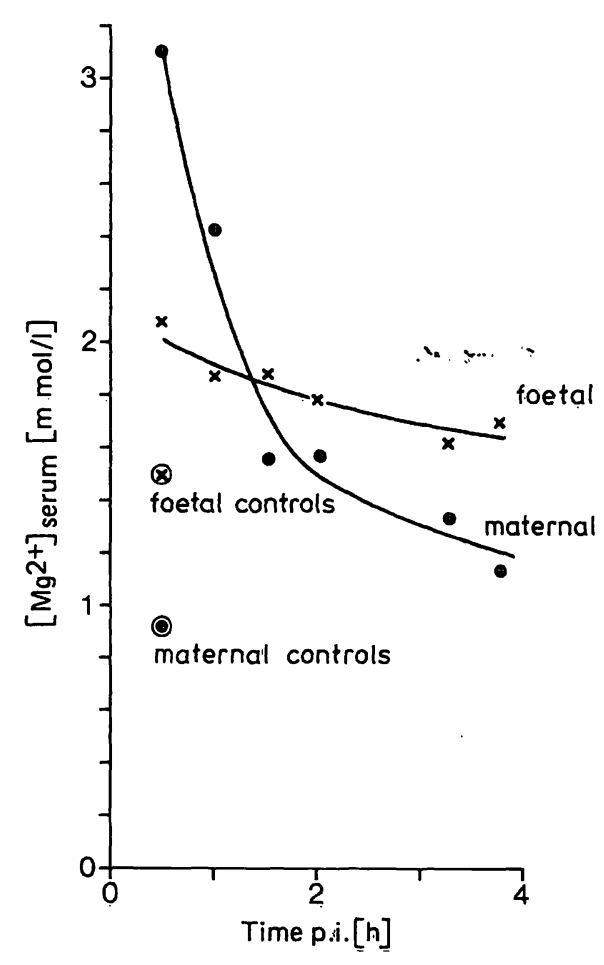

Fig. 5. Foetal $(x-x)$ and maternal $(0-0)$ serum $\mathrm{Mg}^{2+}$ concentration at various times after the last s.c. injection of $1.5 \mathrm{ml} 150 \mathrm{mmol} / 1 \mathrm{MgCl}_{2}$ into pregnant rats (day 19 of gestation). For details see Methods. $\otimes=$ foetal and $O=$ maternal serum $\mathrm{Mg}^{2+}$ concentration of untreated rats.

24 to 28 hours if compared with uninjected rats. Under these conditions, the $\mathrm{Na}^{+}, \mathrm{K}^{+}, \mathrm{Ca}^{2+}$ and $\mathrm{Mg}^{2+}$ contents in foetal hearts and livers were not significantly changed (tạb. 3). 
Tab. 3. $\mathrm{Mg}^{2+}, \mathrm{Ca}^{2+}, \mathrm{Na}^{+}$and $\mathrm{K}^{+}$content in foetal hearts and livers.

Control: foetuses from non-injected pregnant rats. $\mathrm{Mg}^{2+}$ treated foetuses from pregnant rats s. c. injected 7 times from day 18 to 19 with $1.5 \mathrm{ml} 150 \mathrm{mmol} / \mathrm{l} \mathrm{MgCl}$. Foetal tissues of each rat were pooled. $n=$ number of pregnant rats in each group. Mean \pm SEM.

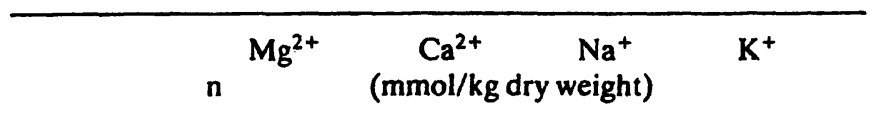

\begin{tabular}{llllll}
\hline Foetal heart & & & & & \\
Control & 4 & $43.5 \pm 0.4$ & $5.7 \pm 0.1$ & $188 \pm 4$ & $490 \pm 8$ \\
$\mathrm{Mg}^{2+}$-treated & 6 & $43.9 \pm 0.3$ & $5.9 \pm 0.3$ & $192 \pm 5$ & $480 \pm 10$ \\
Foetal liver & & & & & \\
Control & 4 & $45.2 \pm 0.6$ & $2.5 \pm 0.1$ & $173 \pm 7$ & $532 \pm 6$ \\
$\mathrm{Mg}^{2+}$-treated & 6 & $45.3 \pm 0.4$ & $2.7 \pm 0.2$ & $166 \pm 13$ & $519 \pm 9$
\end{tabular}

Therefore, in a second experiment, foetal serum $\mathrm{Mg}^{2+}$ was increased further by direct subcutaneous injection of $75 \mu \mathrm{l} 150 \mathrm{mmol} / \mathrm{l} \mathrm{MgCl}_{2}$ into the foetuses. Two hours p.i. foetal serum $\mathrm{Mg}^{2+}$ was increased from $1.38 \pm 0.06 \mathrm{mmol} / \mathrm{l}$ in the control foetuses to $4.81 \pm 0.20 \mathrm{mmol} / \mathrm{l}$ in the $\mathrm{MgCl}_{2}$-injected foetuses. At the same time the tissue $\mathrm{Mg}^{2+}$ of $\mathrm{MgCl}_{2-}$ injected fetuses was slightly increased: In the hearts from $43.3 \pm 1.4 \mathrm{mmol} / \mathrm{kg}$ dry weight to $47.0 \pm 0.9$ $\mathrm{mmol} / \mathrm{kg}$ dry weight, and in the livers from $45.7 \pm$ $0.6 \mathrm{mmol} / \mathrm{kg}$ dry weight to $50.1 \pm 0.4 \mathrm{mmol} / \mathrm{kg}$ dry weight. (Values are given as means $\pm S E M, n=6$ ). The other electrolytes were not changed in the foetuses 2 hours after s.c. injection of $\mathrm{MgCl}_{2}$ (not shown). When extracellular and intracellular $\mathbf{M g}^{2+}$ was calculated from the extracellular fluid volume by means of the $\mathrm{Na}^{+}$space and serum $\mathrm{Mg}^{2+}$ concentrations, no significant increase of intracellular $\mathrm{Mg}^{2+}$ in heart and liver was found (not shown). Therefore, the small increase of $\mathrm{Mg}^{2+}$ content in the tissues of the $\mathrm{MgCl}_{2}$-injected foetuses was caused by the increase in extracellular $\mathrm{Mg}^{2+}$ concentration.

\section{Discussion}

The most significant rèsult of our experiments was the accelerated development of the foetal livers by $\mathrm{MgCl}_{2}$-treatment of their mothers.

From our morphological results, the decrease of glycogen and the development of smooth ER seem to be combined. As the mechanism for the enhanced development of foetal liver by $\mathrm{Mg}^{2+}$ treatment, an increase of the intracellular concentration of $\mathrm{Mg}^{2+}$ or other electrolytes can be excluded, because the cellular electrolyte contents were not changed by the increase in extracellular $\mathrm{Mg}^{2+}$ concentration. This also holds for the drastic increase in foetal serum $\mathrm{Mg}^{2+}$ concentration by direct s.c. injection into the foetuses. Therefore, the precocious decrease of liver glycogen combined with the precocious development of ER may be produced by other mechanisms. These may be an altered foetal hormone secretion and/or an altered activity of regulatory enzymes of glycogen metabolism.

As the onset and early deposition of glycogen occurs at the normal time point in both groups (day 17), the permissive role of glucocorticoid hormones seems to be unaltered by maternal $\mathrm{Mg}^{2+}$ treatment, in agreement with the absence of any morphological alteration of adrenal development.

From a consideration of the biochemical actions of insulin and glucagon, a reduction of the insulin/glucagon ratio could explain the reduction of foetal liver glycogen by glycogenolysis. In normal foetal rats, the insulin/glucagon ratio decreased during the last $2-3$ days of gestation $(6,8,9)$. However, at the same time, the liver glycogen content increases considerably $(5,8,9)$. Therefore, the regulation of glycogen in foetal liver seems to be more complicated, because of the involvement of other components e.g. $\mathrm{Ca}^{2+}$, hormone receptors, adenylate cyclase, cAMP-phosphodiesterase, glycogensynthetase, phosphorylase, phosphorylase phosphatase, synthetase phosphatase (10). Their catalytic activities change during foetal development $(8,9)$, and their kinetic properties are different from the enzymes in adult liver (8), although they have not been defined in detail.

Thus, the precocious glycogenolysis after $\mathrm{Mg}^{2+}$ treatment, may result from an enhanced reduction of the insulin/glucagon ratio.

An altered extracellular $\mathrm{Mg}^{2+} / \mathrm{Ca}^{2+}$-competition at the islet cell membrane is a possible explanation for an altered foetal hormone secretion. When pancreatic islets (from adult animals) were incubated with increased $\mathrm{Mg}^{2+}$-concentration at constant $\mathrm{Ca}^{2+}$-concentration, insulin secretion was decreased $(11,12)$, although this effect was only significant at rather high $\mathrm{Mg}^{2+}$-concentration $(11,12)$. However, it is not known whether insulin and glucagon secretion of foetal pancreatic islets shows the same sensitivity to increased extracellular $\mathrm{Mg}^{2+}$ as in the adult pancreas.

As glucose-6-phosphatase is bound to ER, the enhanced development of this organelle after $\mathrm{Mg}^{2+}$ treatment may be evidence for increased glycogenolysis by another mechanism. This enzyme, inducible by glucagon (8), can reduce the glucose- 6 -phosphate 
concentration. As glucose-6-phosphate is an allosteric activator of glycogen synthetase, a precocious decrease in glucose-6-phosphate may be responsible for a lower synthesis of glycogen and thus a precocious decrease in glycogen content.

However, other enzymes, regulating synthesis and degradation of glycogen may be also changed by the $\mathrm{Mg}^{2+}$-treatment. Moreover, $\mathrm{MgCl}_{2}$-treatment may change the concentration of intracellular free $\mathrm{Ca}^{2+}$, which is also involved in glycogen metabolism (10).

\section{References}

1. Conradt. A. \& Weidinger, H. (1982) Magnesium-Bull. 4, 103-124.

2. Oliveira-Filho, R. M., Kulay Jr. L., Medeiros, L. O. Medeiros, L. F., Valle, L. B. S. \& De Luca, R. (1983) Gen. Pharmacol. 14, 291-294.

3. Vormann, J., Förster, R. \& Günther, T. (1983) J. Clin. Chem. Clin. Biochem. 2I, 765-773.

4. Neubert, D., Gregg, C. T., Bass, R., Merker, H. J. (1975) In: The biochemistry of animal development. (Weber, R., ed.) pp. 387-464. Acad. Press, New York, San Francisco, London.

5. Greengard, O. \& Dewey, H. K. (1970) Development. Biol. $21,452-461$.
Because of the very low cytosolic $\mathrm{Ca}^{2+}$ concentration and strong compartmentalization, the participation of $\mathrm{Ca}^{2+}$ cannot be determined by measuring the total $\mathrm{Ca}^{2+}$ content of the liver. More experiments are needed to clarify the regulatory mechanisms of glycogen metabolism in normal and $\mathbf{M g}^{2+}$-treated foetal livers. The enhanced development of excretory pancreas may be related to the enhanced development of its ER. The mechanism may be similar to the increase of $\mathrm{ER}$ in the foetal liver after $\mathrm{Mg}^{2+}$-treatment.

6. Di Marco, P. N., Chisalberti, A. V., Martin, C. E. \& Oliver, T. (1978) Eur. J. Biochem. 87, 243-247.

7. Nielsen, S. P. (1973) Calcif. Tissue Res. 11, 78-94.

8. Böhme, H. J., Sparmann, G. \& Hofmann, E. (1983) Experientia 39, 473-483.

9. Margolis, R. N. (1983) Endocrinology 113, 893-902.

10. Hems, D. A. \& Whitton, P. D. (1980) Physiol. Rev. 60, $1-50$.

11. Atwater, I., Frankel, B. J., Rojas, E. \& Grodsky, G. M. (1983) Quart. J. Exptl. Physiol. 68, 233-245.

12. Berggren, O.-P., Bergsten, P., Gylfe, E., Larsson, R. \& Hellman, B. (1983) Am. J. Physiol. 244, E 541-E 547.

Prof. Dr. T. Günther

Institut für

Molekularbiologie und Biochemie

Arnimallee 22

D-1000 Berlin 33

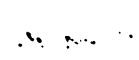

